Original Paper $\quad$ http://ajol.info/index.php/ijbcs $\quad$ http://indexmedicus.afro.who.int

\title{
Floristic diversity and structural characteristics of woody savanna vegetation: a case study from Patako Forest (Senegal)
}

\author{
Simon SAMBOU ${ }^{*}$, Fatimata Niang DIOP ${ }^{1}$, Sara Danièle DIENG ${ }^{1}$, \\ Laurice Codou FAYE ${ }^{1}$, Bienvenu SAMBOU ${ }^{1}$, Assane GOUDIABY ${ }^{1}$, Cheikh MBOW ${ }^{1,2}$ \\ and Anne Mette LYKKE ${ }^{3}$
}
${ }^{I}$ Université Cheikh Anta Diop de Dakar, Faculté des Sciences et Techniques, Institut des Sciences de l'Environnement, Dakar-Fann, Senegal.
${ }^{2}$ Future Africa Institute, University of Pretoria, South Africa.
${ }^{3}$ Aarhus University, Department of Bioscience, Silkeborg, Denmark.
${ }^{*}$ Corresponding author; E-mail: sambousimon@gmail.com ; Tel. (+221) 775388126

\begin{tabular}{ccc}
\hline Received: 23-06-2021 & Accepted: 15-10-2021 & Published: 30-10-2021 \\
\hline
\end{tabular}

\begin{abstract}
Due to the presence of tree species of high socio-economic importance, many protected areas in the sudanian zone are facing anthropogenic pressure that threatens their stability and resources integrity. This study aimed at providing a better understanding of woody plant composition and structure in Patako Forest in Senegal. Data collection was conducted by stratified random sampling in a total of 251 plots in different vegetation types. The results indicated that Combretum glutinosum, Terminalia macroptera, Cordyla pinnata, Elaeis guineensis, Acacia macrostachya and Khaya senegalensis were the most representative species. The Importance Value Indices (IVI) of these species varied significantly among vegetation types. Species diversity and structural characteristics were higher in gallery forest. The most important Shannon diversity indices was recorded in gallery forest (2.81) while it was medium in both woodland (2.12), tree savanna (1.55) and shrub savanna (1.24). Tree density was dominated by multi-stemmed species. Stem density was significantly higher in gallery forest (536 \pm 13 per ha) and woodland ( $526 \pm 12$ per ha) than in tree savanna (364 \pm 15 per ha) and shrub savanna (309 \pm 14 per ha). Forest management should focus on gallery forest to enhance biodiversity conservation and increase the potential of carbon sequestration.
\end{abstract}

(C) 2021 International Formulae Group. All rights reserved.

Keywords: Biodiversity, vegetation structure, savanna vegetation, protected area, Saloum Delta.

\section{INTRODUCTION}

For some decades, biodiversity conservation, especially in tropical areas, has granted a particular interest for the international community. This interest led to the implementation of the Convention on Biological Diversity (CBD) which objectives have been materialized in the framework of the national strategies for sustainable management of forest resources (Lele et al., 2010). Countries were encouraged to periodically assess the state of biodiversity. However, diverse causes led to biodiversity loss even in protected areas due to complex interactions of various drivers (Porter-Bolland et al., 2012). These concerned rapid population growth, 
rural poverty and human disturbances such as tree cutting, agricultural expansion and animal grazing (Chazdon, 2008; Stork, 2010). These disturbances are known to increase the vulnerability of ecosystems especially in nonmanaged forests.

Vegetation degradation has often been reported in West Africa, defined as the decline in forest productivity or its capability to assume the roles and functions of providing goods, services and benefits supply (Thompson et al., 2013). These measures consisted in ensuring integrated and sustainable management of natural resources, including forests, tree cover and biodiversity.

Usually, species diversity is studied using different indices (Gotelli and Colwell, 2001). Some of the indices take into account the presence or absence of the recorded species in the samples. Furthermore, others ones integrate information on the relative abundance and relative frequency of the species. However, there are diversity indices that depend on sample size (Magurran, 2004), where as alpha $(\alpha)$ and gamma $(\gamma)$ diversity are only differentiated by the scale (Jurasinski et al., $2009)$. As for Beta ( $\beta$ ) diversity it related to the difference in species composition between communities (Sfenthourakis and Panitsa, 2012).

The knowledge of tree diversity is a challenge even in fragmented savanna's ecosystems. To address this challenge and provide reliable information that support the implementation of a management plan, some basic data are required. Patako Forest is surrounded on both sides by a multitude of villages whose population livelihoods directly or indirectly depends on the exploitation of forest resources derived from it (Diop et al., 2011). The important livelihood activities include tree logging for fuelwood, timber, nontimber forest products, market gardening and grazing. These activities improved the daily lives of local communities but have implications on woody plant species diversity and structure.

Considering the existing biodiversity potential in Patako Forest and the important role it plays in supplying ecosystem goods and services, native species have been identified in order to break the pressure from rural communities. Indeed, to support the conservation of useful tree species, an afforestation/reforestation project-based Payment for Ecosystem Services (PES) was implemented around the protected area with the purpose to enhance biodiversity conservation by empowering local farmers to grow trees and restore the degraded landscape. The adopted land management systems integrated biodiversity for a variety of uses, thereby minimizing the exploitation of the protected area (Huang et al., 2002). The present study aimed at getting a global insight into diversity and structural characteristics of woody vegetation in Patako Forest by assessing the floristic composition, the diversity and the structure of the various vegetation types.

\section{MATERIALS AND METHODS Study area}

The study was conducted in the Patako Forest located in the Saloum Delta region of Senegal (West Africa). Patako Forest is a protected area (established in 1934) covering 5638 ha and located between two rural councils (Keur Saloum Diane and Keur Samba Gueye) (Figure 1). The status of protection is governed by law which provisionally prohibit the exploitation excepted some uses like dead wood and fruit collection. Classified forest requires the development of a management plan as a prerequisite for the use of their resources. A short rainy season from June to October with a monomodal pattern and a dry season from November to May characterize the climate of the study area. The mean annual rainfall ranges between 600 and $800 \mathrm{~mm}$ with high temperatures throughout the year which average $26.6^{\circ} \mathrm{C}$. The area is dominated by ferruginous tropical soils, poorly evolved soils, hydromorphic soils on alluvial plains and gleysalted soils along valleys. These pedoclimatic conditions influence the distribution of vegetation. The latter is dominated by sudanian savannas generally with short cycle grasses due to fire frequencies. The vegetation types consist of shrub and tree savanna. Gallery 
forests grow along two principal valleys and a mangrove area is found at their junction.

The woody vegetation consisted of at least $73 \%$ of species exploited for wood energy, $14 \%$ for timber and $4 \%$ for non-timber forest products (Sambou, 2004). These forest resources play a key role in the rural communities' livelihoods because of their multiple uses in the fields of local wood technology, food (fruits, leaves, flowers, gum, roots), traditional medicines. Patako Forest has several species with edible fruits which has spurred an important gathering activity involving women and young people in fruits havesting for consumption or sale in local weekly markets (luuma).

\section{Sampling design and data collection}

Data collection was carried out within four vegetation types (shrub savanna, tree savanna, woodland and gallery forest) identified based on a stratification using Landsat images (Sambou et al., 2015). Each of these main vegetation types was divided into grids of $250 \mathrm{~m} \times 250 \mathrm{~m}$ which constitute the "survey population". The number of grids depends on the size of each vegetation types. Then, the homogeneous grids (covered by a single vegetation type) were identified and selected on the basis of a simple random sampling without replacement (Sambou et al., 2007). Furthermore within each selected grid, 8 plots of 0.04 ha $(20 \times 20 \mathrm{~m})$ each one were randomly installed along the medians and the diagonals (Figure 2). Data collection using this sampling design was conducted in a total of 216 plots with 56 in woodland, 144 in tree savanna and 16 in shrub savanna. Concerning the gallery forest, 35 rectangular plots $(10 \mathrm{~m} \times$ $40 \mathrm{~m}$, i.e. 0.04 ha) were also randomly surveyed. The survey covered a total of 10.04 ha, e.g: sampling rate of $0.18 \%$. In each plot, we measured trees with diameter at breast height (DBH) at $1.3 \mathrm{~m}$ above the ground level $\geq 5 \mathrm{~cm}$. The minimum sample size $(N)$ required was computed with a margin error (d) of 5\% using the following formula (Dagnelie 1998):

$$
N=\left(\frac{t^{2}{ }_{1-\frac{\alpha}{2}} \times C V^{2}}{d^{2}}\right)
$$

Where $N$ is the size of the sample, ${ }_{1-\frac{\alpha}{2}}$ the value of $t$ distribution (1.96) with a probability of $0.975(\alpha=0.05)$ and $C V$, the coefficient of variation of the basal area of each vegetation type.

\section{Data analysis}

\section{Floristic composition}

The Importance Value Indices (IVI) of tree species were calculated. For a species $i$, IVI is the summation of the relative density $\left(\mathrm{RD}_{i}\right)$, relative dominance $\left(\mathrm{RDo}_{i}\right)$ and relative frequency $\left(\mathrm{RF}_{i}\right)$, as:

$$
I V I_{i}=R D_{i}+R D o_{i}+R F_{i}
$$

$\mathrm{RD}_{i}$ was obtained by dividing the number of individual trees belonging to species $_{i}$ by the total number of individuals $\mathrm{x}$ 100; $\mathrm{RDo}_{i}$ was derived from the division of the species $_{i}$ basal area by the total basal area of all species $\mathrm{x} 100$; and $\mathrm{RF}_{i}$ is the frequency of a given species divided by the total frequency of all species $x$ 100. The basal area of a vegetation type (G), i.e. the sum of the cross-sectional area at $1.3 \mathrm{~m}$ above the ground level of all trees on a plot, expressed in $\mathrm{m}^{2} /$ ha was calculated as follow:

$$
G=\frac{\pi}{4 s} \sum_{i=1}^{n} 0.0001 d_{i}^{2}
$$

$\mathrm{d}_{i}$ is the diameter (in $\mathrm{cm}$ ) of the $i^{\text {th }}$ tree of the plot; $\mathrm{s}=0.04$ ha.

\section{Floristic diversity}

Species richness (S) was calculated as the total number of species recorded within each vegetation type.

Shannon Weaver diversity index (H') was calculated as:

$$
H^{\prime}=-\sum_{i=1}^{s} p_{i} \ln p_{i}
$$

Where $p$ is the proportion $(n / N)$ of individuals of one particular species found $(n)$ divided by the total number of individuals found $(N), \ln$ is the natural $\log , \Sigma$ is the sum of the calculations, and $s$ is the number of species.

Simpson index was calculated as 


$$
D=1-\sum \frac{n_{i}\left(n_{i}-1\right)}{N(N-1)}
$$

Where $\mathrm{n}_{i}$ is the number of individuals for a given species and $N$ the total number of individuals.

Pielou evenness index ( $\left.\mathrm{J}^{\prime}\right)$ was calculated as

$$
J^{\prime \prime}=\frac{H^{\prime}}{H^{\prime}{ }_{\max }}=\frac{H^{\prime}}{\ln (S)}
$$

Additive diversity partition expresses $\alpha$ and $\beta$ diversity in the same unit so that their relative importance can be compared across vegetation types (Crist and Veech, 2006). ais defined as the average of the species richness (number) in the surveyed plots $(n)$ at a site and $\beta$ the variation in species composition among sites.

The analysis of vegetation indices was done using the open source statistical software $\mathrm{R}$ and Biodiversity $\mathrm{R}$ packages.

\section{Vegetation structure}

Weibull distribution was used to characterize the size class distribution (Sheykholeslami et al., 2011). The structure of each vegetation type was adjusted to the Weibull parameters which density function $f$ is expressed for a stem diameter $x$ as follows:

$$
f(x)=\frac{c}{b}\left(\frac{x-a}{b}\right)^{c-1} \exp \left[-\left(\frac{x-a}{b}\right)^{c}\right]
$$

Where $x=$ the stem diameter ; $a=$ the position parameter equal to 5 in this study; $b=$ the size or scale parameter and $c=$ the shape parameter.

Data analysis was performed using Minitab. In order to test the adequacy between the observed density and the theoretical Weibull density, log-linear tests were performed with the following model (Caswell, 2001) using SAS software.

LogFrequence $=F+F_{-}$Class $+F_{-}$Adjustment $+\varepsilon$

$\mathrm{F}=$ mean frequency of the classes; $\mathrm{F} \_$Class = non-random gap linked to the differences in frequency between classes; F_Adjustment = non-random gap linked to differences between observed and theoretical frequencies; $\varepsilon$ is the error of the model. The hypothesis of adequacy between both distributions is accepted if the probability value of the test is higher than 0.05 . One way ANOVA and Tukey test were performed to compare means by vegetation types and assess their level of significance.

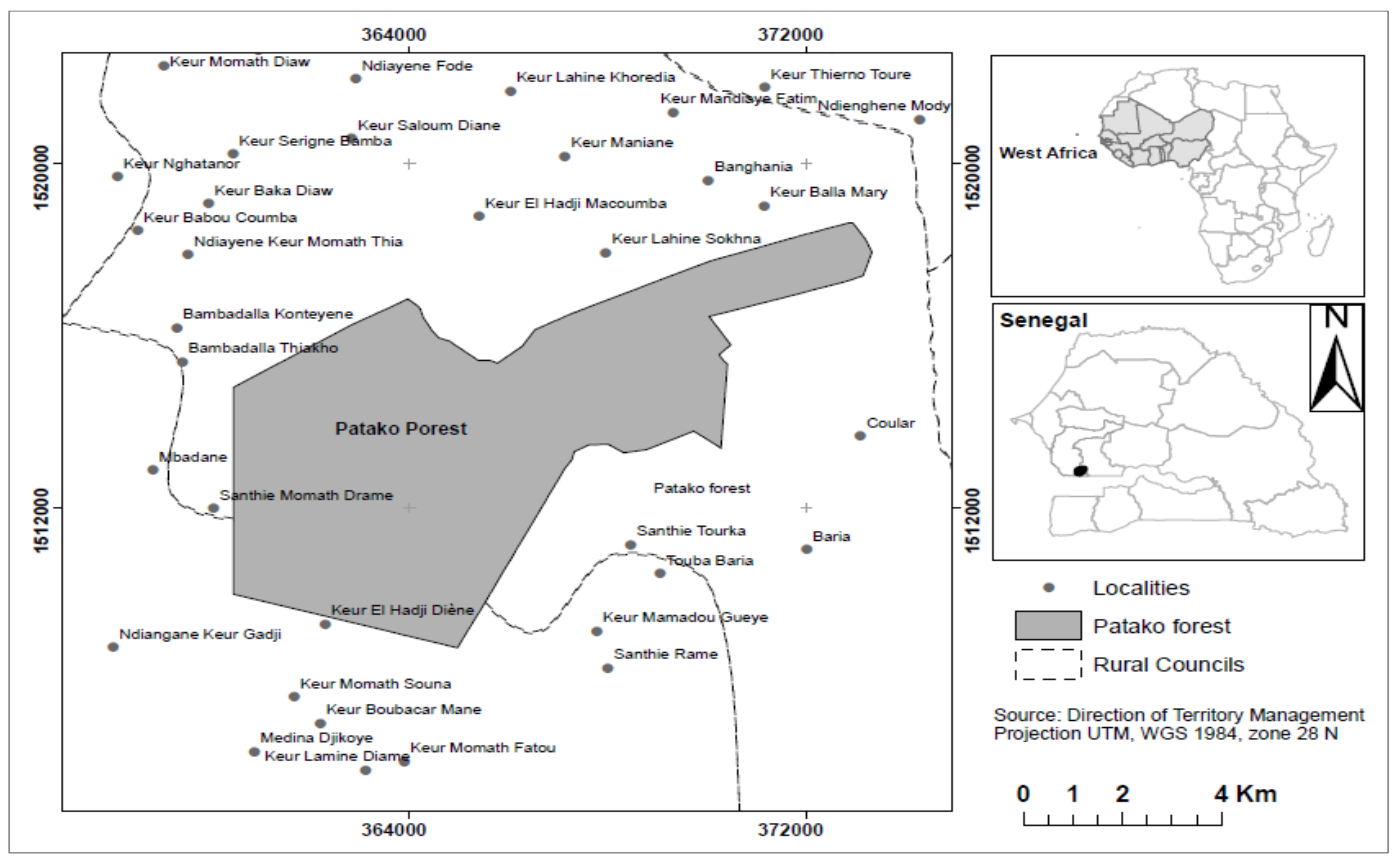

Figure 1: Location of Patako Forest. 


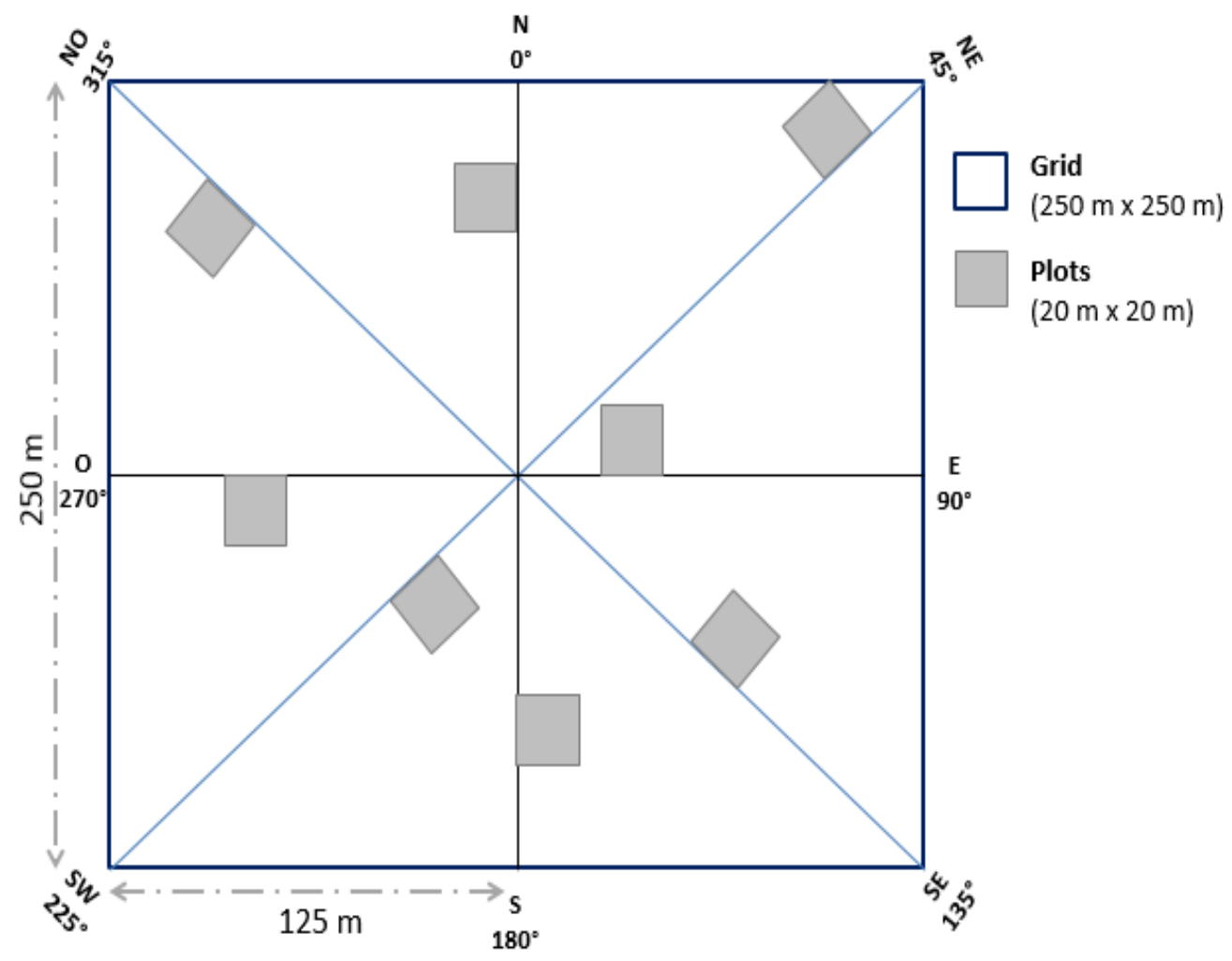

Figure 2: Sampling design for data collection.

\section{RESULTS}

\section{Floristic composition}

A total of 102 species belonging to 81 genera and 35 families were recorded. The most abundant family was Fabaceae divided into three subfamilies namely Caesalpinioideae (7 genera), Faboideae (7 genera) and Mimosoideae (6 genera). This family consisted of 25 species and represented $24.5 \%$ of the total recorded species. Combretaceae included 11 species divided into 3 genera (Figure 3). The Anacardiaceae and Moraceae counted 7 genera each of them, 5 and 3 species respectively. For the remaining families, it was generally noted the same distribution of genera among species.

Two recorded species have a fully protected status (i.e. Diospyros mespiliformis and Dalbergia melanoxylon) and 9 others a partially protected status (i.e. Adansonia digitate, Ceiba pentendra, Cordyla pinnata,
Khaya senegalensis, Prosopis Africana, Pterocarpus erinaceus, Sclerocarya birrea, Tamarindus indica and Ziziphus mauritiana).

Generally 21 species represented more than $90 \%$ of the IVI. Some species were recorded in all types of vegetation while others were specific to the gallery forest. Combretum glutinosum was the most abundant species in all vegetation types except in gallery forest, with a very high IVI of 160.62 and 109.57 in shrub savanna and tree savanna, respectively (Table 1). These values respectively counted for $54 \%$ and $37 \%$ of the total IVI estimated in the two vegetation types. It was particularly characterized by large frequencies of relative density, relative dominance and relative frequency. In the woodland, Terminalia macroptera and Combretum glutinosum had the highest IVI with 77.92 and 76.01, respectively. In the gallery forest Elaeis guineensis and Khaya senegalensis recorded 
the highest IVI values with 47.05 and 38.52 respectively, which accounts both for $29 \%$ of the total.

\section{Plant species richness and diversity}

The diversity indices varied from a vegetation type to another (Table 2). Species richness was estimated to 76 species with an average of $12.9 \pm 4.64$ per plot in the gallery forest, and 20 species with $4.75 \pm 1.65$ per plot in shrub savanna. Shannon index $\left(\mathrm{H}^{\prime}\right)$ was 2.81 in the gallery forest whereas 0.89 was found for Simpson index. Woodland recorded a diversity of $H^{\prime}=2.12, D=0.82$. Tree savanna and shrub savanna were the least diversified vegetation types with $\mathrm{H}^{\prime}=1.55, \mathrm{D}=0.63$; and $\mathrm{H}^{\prime}=1.24$, $\mathrm{D}=0.54$ respectively. But the number of tree individuals among species follow the same distribution except for shrub savanna in which a high variability $(0.70 \pm 0.19)$ was recorded. This variability of J' evenness based Shannon's diversity index was estimated to $0.74 \pm 0.05$ in woodland. As for the gallery forest $\mathrm{J}^{\prime}=0.65$ and for the woodland $\mathrm{J}^{\prime}=0.59$.

The contribution of $\alpha$ and $\beta$ diversity to $\gamma$ diversity differs among the different vegetation types of Patako forest. The $\beta$ had a slightly greater contribution in all types except for the gallery forest where $\alpha=12.14 \pm 4.67$ represents $59.10 \%$ of $\gamma$ (Table 2).

The shared common species varied from 13 to 31 between all vegetation types with an average of $20.33 \pm 6.41$. The savanna vegetation types (i.e shrub savanna, tree savanna and woodland) have Sorrensen similarity indices greater than 0.5 (ranging from 0.54 to 0.75 ). Tree savanna and woodland were the most similar types $(0.75)$ where as shrub savanna and gallery forest shared fewer species.

\section{Structure of woody vegetation}

The highest density was observed within the gallery forest $(412 \pm 11$ trees/ha) followed by the woodland ( $390 \pm 23$ trees/ha), tree savanna $277 \pm 18$ trees/ha and shrub savanna (192 \pm 17 trees/ha). In most cases tree species were multi-stemmed. Stems density ranged from $309 \pm 14$ to $536 \pm 13$ per ha with a lower number in the shrub savanna (Table 3 ). The ANOVA based multiple comparison of means showed in general significant differences $(P<0.001)$ between the studied vegetation types.

The mean diameter ranged from $9.60 \pm$ 5.87 in the shrub savanna to $18.30 \pm 16.66 \mathrm{~cm}$ in the gallery forest. There was also a large variability within one type and among vegetation types and species. The majority of trees and stems were distributed within the smaller diameter classes. This DBH distribution illustrated the weakness of the basal area in the savanna vegetation types (between $3.08 \pm 1.82 \mathrm{~m}^{2} / \mathrm{ha}$ and $6.82 \pm 3.45$ $\mathrm{m}^{2} / \mathrm{ha}$ ) compared with gallery forest $(25.78 \pm$ $14.43 \mathrm{~m}^{2} / \mathrm{ha}$ ).

The observed size class distribution revealed a reversed $\mathrm{J}$-shape distribution (Figure 4). The species that influenced most this structure were Combretum glutinosum, Combretum nigricans, Terminalia macroptera, Acacia macrostachya. They represented over $60 \%$ of the measured individual trees. These species were characterized by small or medium size class diameters. Individuals with large diameter $(\mathrm{DBH}>50 \mathrm{~cm})$ were less represented in the savanna vegetation types (density $=2$ per ha) than in the gallery forest (density $=20$ per ha) where some species such as Khaya senegalensis, Detarium senegalense, Ceiba pentandra, and Elaeis guineense are exclusively located.

The shape parameter (c) of Weibull was inferior to 1 in all vegetation types; shrub savanna (0.846), woodland (0.834), tree savanna (0.780) and gallery forest (0.699). Log-linear tests revealed that the theoretical distribution of Weibull fitted $(p>0.05)$ the observed structure in all vegetation types. 


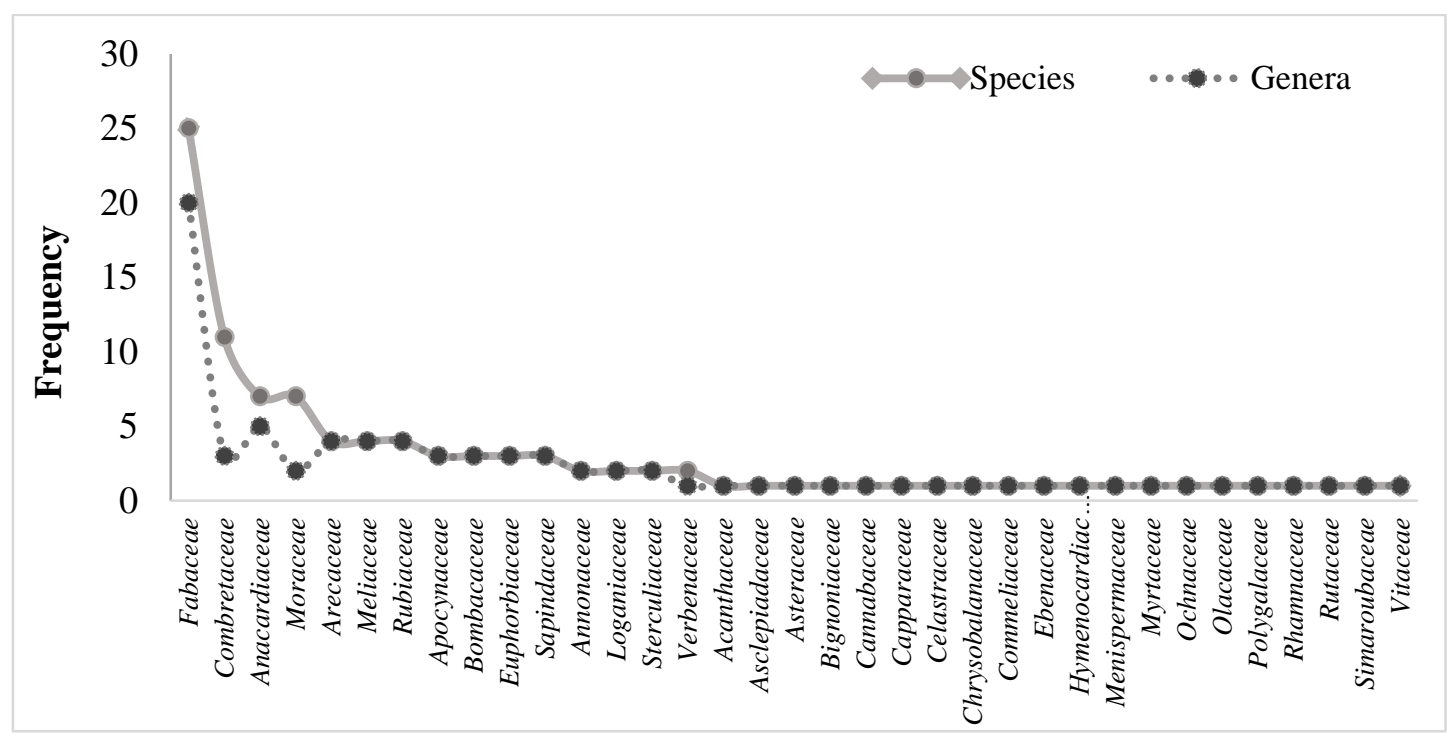

Figure 3: Distribution of woody vegetation by family and genera.

Table 1: The five tree species with highest IVI in each vegetation type.

\begin{tabular}{|c|c|c|c|c|}
\hline Tree species & RD (\%) & RDo (\%) & FR (\%) & IVI \\
\hline \multicolumn{5}{|l|}{ Shrub savanna } \\
\hline Combretum glutinoswn Perr. ex DC. & 70.73 & 57.98 & 31.91 & 160.62 \\
\hline Combretum nigricans Lepr. ex Guill. Et Perr. & 7.32 & 8.57 & 17.02 & 32.91 \\
\hline Cordyla pinnata (Lepr. ex A. Rich) Milne-Redhead & 4.07 & 16.27 & 10.64 & 30.97 \\
\hline Terminalia avicennioides Guill. et Perr. & 8.94 & 5.47 & 10.64 & 25.05 \\
\hline Terminalia macroptera Guill. et Perr. & 2.44 & 1.87 & 8.51 & 12.82 \\
\hline Others & 6.5 & 9.84 & 21.28 & 37.63 \\
\hline \multicolumn{5}{|l|}{ Tree savanna } \\
\hline Combretum glutinoswm Perr. ex DC. & 48.62 & 44.55 & 16.40 & 109.57 \\
\hline Terminalia macroptera Guill. et Perr. & 15.54 & 12.18 & 12.30 & 40.02 \\
\hline Acacia macrostachya Reichenb. ex DC. & 13.53 & 5.85 & 9.34 & 28.72 \\
\hline Cordyla pinnata (Lepr. ex A. Rich) Milne-Redhead & 2.51 & 10.67 & 6.95 & 20.13 \\
\hline Lannea acida A .Rich. & 2.44 & 6.57 & 5.69 & 14.71 \\
\hline \multicolumn{5}{|l|}{ Woodland } \\
\hline Terminalia macroptera Guill. et Perr. & 34.94 & 28.51 & 14.47 & 77.92 \\
\hline Combretum glutinoswn Perr. ex DC. & 31.96 & 30.10 & 13.95 & 76.01 \\
\hline Cordyla pinnata (Lepr. ex A. Rich) Milne-Redhead & 3.67 & 13.04 & 6.20 & 22.91 \\
\hline Acacia macrostachya Reichenb. ex DC. & 6.64 & 4.10 & 6.98 & 17.72 \\
\hline Daniellia olveri (Rolfe) Hutch. \& Dalz. & 2.06 & 6.84 & 4.65 & 13.55 \\
\hline \multirow{2}{*}{\multicolumn{5}{|c|}{ Gallery forest }} \\
\hline & & & & \\
\hline Elaeis guineensis Jacq. & 20.34 & 17.33 & 9.38 & 47.05 \\
\hline Khaya senegalens is (Desr.) A. Juss. & 7.41 & 24.17 & 6.94 & 38.52 \\
\hline Ceiba pentandra (L.) Gaertn. & 0.69 & 17.53 & 1.04 & 19.26 \\
\hline Detarium senegalense J.F.Gmel. & \multirow{2}{*}{\multicolumn{2}{|c|}{ Activer 2.31 ind 06.67}} & 5.90 & 16.88 \\
\hline Cola cordifolia (Cav.) R. Br. & & & 3.13 & 12.87 \\
\hline Others & \multicolumn{4}{|c|}{ Accédez 65.01 para 26.80} \\
\hline
\end{tabular}

IVI is the Importance Value Indice, $\mathrm{RD}_{i}$ the relative density, $\mathrm{RDo}_{i}$ the relative dominance and $\mathrm{RF}_{i}$ the relative frequency. 
Table 2: Woody vegetation diversity in Patako Forest. Diversity indices and their variability (mean and standard deviation) for each vegetation type.

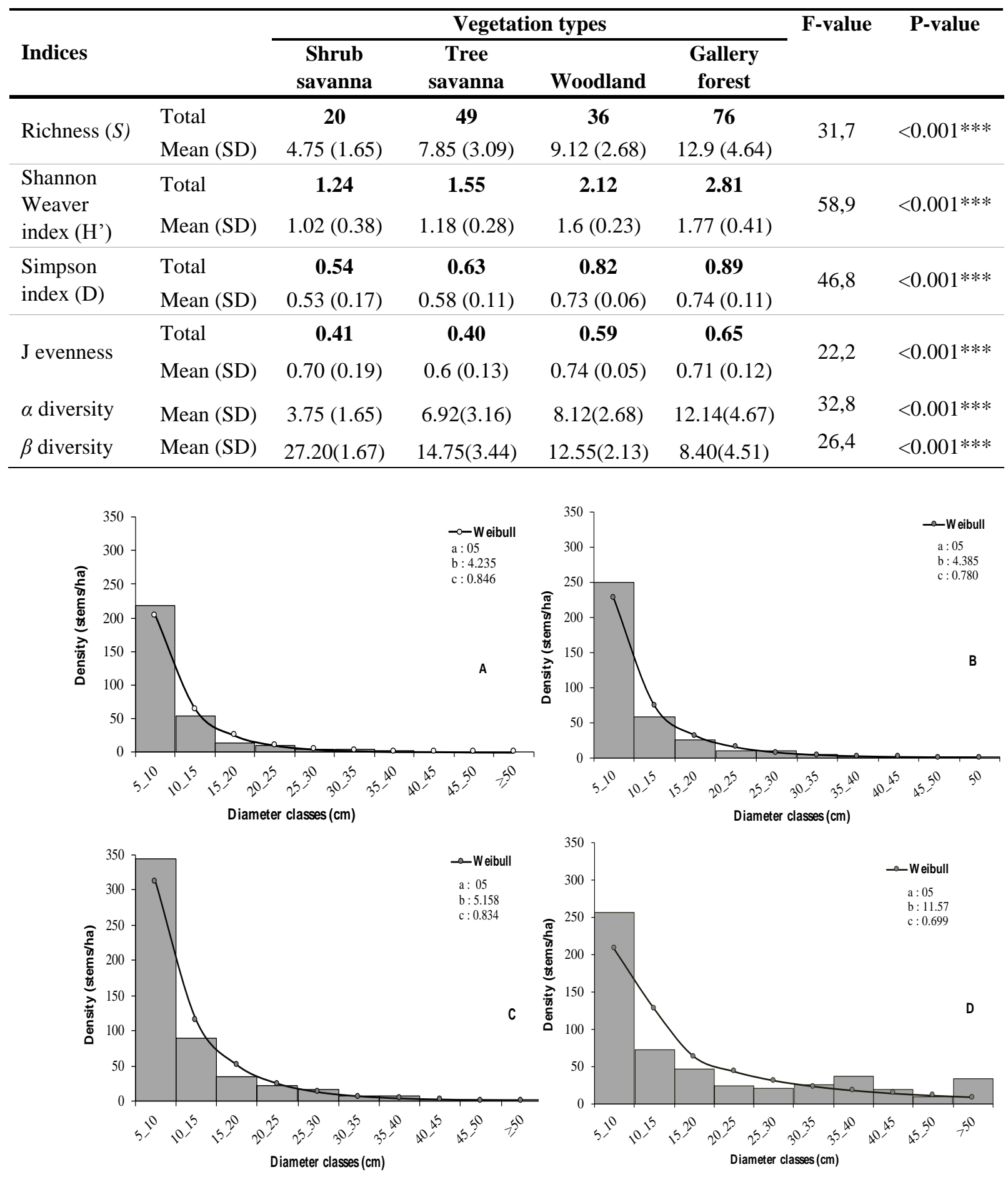

Figure 4: Diameter structure of Patako Forest vegetation types.

A : shrub savanna ; B : tree savanna ; : woodland ; D : gallery forest and $a, b, c$ are respectively the position, the size or scale and the shape parameters of Weibull distribution. 
Table 3: Structural parameters of trees $\geq 5 \mathrm{~cm} \mathrm{DBH}$ in Patako Forest.

\begin{tabular}{|c|c|c|c|c|c|c|}
\hline $\begin{array}{l}\text { Vegetation } \\
\text { types }\end{array}$ & $\begin{array}{c}\begin{array}{c}\text { Shrub } \\
\text { savanna }\end{array} \\
\text { Mean } \pm \text { SD }\end{array}$ & $\begin{array}{c}\text { Tree } \\
\text { savanna } \\
\text { Mean } \pm \text { SD }\end{array}$ & $\begin{array}{c}\text { Woodland } \\
\text { Mean } \pm \text { SD }\end{array}$ & $\begin{array}{c}\begin{array}{c}\text { Gallery } \\
\text { forest }\end{array} \\
\text { Mean } \pm \text { SD }\end{array}$ & $\begin{array}{c}F- \\
\text { value }\end{array}$ & $\operatorname{Pr}(>F)$ \\
\hline $\begin{array}{l}\text { Density } \\
\text { (individuals/ha) }\end{array}$ & $192 \pm 17$ & $277 \pm 18$ & $390 \pm 23$ & $412 \pm 11$ & 15.07 & $\begin{array}{r}<0.001 \\
* * *\end{array}$ \\
\hline $\begin{array}{l}\text { Density } \\
\text { (stems/ha) }\end{array}$ & $309 \pm 14$ & $364 \pm 15$ & $526 \pm 12$ & $536 \pm 13$ & 16.71 & $\begin{array}{r}<0.001 \\
* * * *\end{array}$ \\
\hline $\begin{array}{l}\text { Mean DBH } \\
(\mathrm{cm})\end{array}$ & $9.60 \pm 5.87$ & $\begin{array}{l}10.10 \pm \\
7.05\end{array}$ & $\begin{array}{c}10.70 \pm \\
7.12\end{array}$ & $\begin{array}{c}18.30 \pm \\
16.66\end{array}$ & 44.68 & $\begin{array}{r}<0.001 \\
* * *\end{array}$ \\
\hline $\begin{array}{l}\text { Basal area } \\
\left(\mathrm{m}^{2} / \mathrm{ha}\right)\end{array}$ & $3.08 \pm 1.82$ & $3.97 \pm 3.52$ & $6.82 \pm 3.45$ & $\begin{array}{c}25.78 \pm \\
14.43\end{array}$ & 33.45 & $\begin{array}{r}<0.001 \\
* * *\end{array}$ \\
\hline
\end{tabular}

\section{DISCUSSION}

\section{Floristic composition}

An important number of plant families, genera and species were reported in the Patako Forest. Our findings have demonstrated a higher tree diversity compared to a previous study in which 73 species belonging to 63 genera and 28 families were found in the area within 176 sample plots of 0.04 ha each one (Sambou et al., 2007). But these authors did not take into account gallery forest. As a comparison, if we exclude the gallery forest, the number of recorded species was approximately the same with only 6 more species found in the current study. This shows the importance of the gallery forest and its contribution to the knowledge of Patako Forest biodiversity potential.

Plant richness in Senegal was estimated to 2499 species divided into 182 genera and 1022 families (Ba and Noba, 2001). Considering the scale of data survey (5638 ha) and the number of recorded species we can state that the studied area has a great biodiversity potential, though unevenly distributed from one vegetation type to another.

In the savanna vegetation Combretum glutinosum and Terminalia macroptera were the most important species in terms of IVI due to their high density, frequency and basal area. These species are among the dominant and most havested by local populations especially for fuelwood. Ouoba and $\mathrm{Da}$ (2019) considered that the high presence of Combretaceae in some natural vegetation is due to their ability to resist disturbances. The cumulative impacts of stems cutting could explain the dominance of some species due to their regenerative power. This can increase as a function of stress due to historic damages.

In order to stop human pressure, Arlomom project was initiated in 2010 as an innovative approach to enhance technical and leadership capacity of local communities and restore degraded lands. This initiative aimed at developping sustainable land management practices that combine existing and improved agricultural land uses with tree planting and assisted natural regeneration. These afforestation and agroforestry activities were implemented with native tree species in order to conserve biodiversity. An inclusive approach was used with ecological and socioeconomical criteria allowing communities to prioritized and choose species based on their needs and preferences. The planted trees allowed, in a short and medium terms, local people to restore tree cover in the degraded agricultural lands, fertilize soil, gain additional revenue through the payment of ecosystem services. Later the households can satisfy their needs of wood harvesting for cooking outsite the protected area.

For the gallery forest, Elaeis guineensis and Khaya senegalensis were the dominant species and have been especially recorded within this humid environment which ecological conditions are different to other types. The gallery forest is drained by two valleys and one of them has a permanent flow 
with fresh water upstream. Such conditions have supported the development of rare species with low IVI values, but which are of paramount importance in providing goods for local communities (e.g: Saba senegalensis, Detarium senegalense, Dialium guineense, Landolphia heudelotii).

The relative species richness of Patako Forest could be attributed to habitat heterogeneity as these conditions have been deemed to increase tree diversity of African savannas. Water availability in soils is a determinant factor of vegetation growth, composition and distribution of savanna ecosystems (Gnoumou et al., 2020). Despite its location in the Sudanese domain the study site is one of the northern most refuge of Guinean plant species (Elaeis guineensis, Dialium guineense, Erytrophleum guineense). There are also Sudano-Guinean plant species mainly located along the Patako gallery forest: Ficus glumosa var glaberrima, Ficus sycomorus, Ficus platyphylla, Neocarya macrophylla, Detarium senegalense, Alchornea cordifolia, Fagara xanthoxyloides. According to Diop et al. (2012), the Ficus species listed above are mainly frequent in the humid forests of the Casamance, the gallery forests and the humid valleys of eastern Senegal. Due to favorable ecological conditions existing in the Patako Forest valleys some species have adapted out of their eco-climatic zone. According to the national forestry Code, Senegal has listed 11 ligneous tree species with a fully protected status and Patako forest counts 18\% among them, while it records $53 \%$ of the partially protected species. Most of the recorded species were native except for Azadirachta indica, which was identified as an exotic species and whose few tree individuals were probably disseminated by frugivorous birds.

\section{Diversity of woody plant species}

Most indices showed that species diversity concentrated in the gallery forest as opposed to the shrub savanna where smaller values were estimated. Shannon index showed values greater than 1.5 in the main vegetation types, except in the shrub savanna. This could be due to the difference in sampling intensity among vegetation types (Magurran, 2004).
However, the recorded values highlight the potential of Patako Forest as a sink of biodiversity. This potential was especially illustrated through a good distribution of individuals among species $\left(\mathrm{J}^{\prime}=0.96\right)$. Simpson index (D) further confirmed species diversity of the gallery forest, woodland and tree savanna. Within these types, D was significantly higher than 0.5 . This index was recognized to be one of the most meaningful and robust diversity measures as it takes into account the variance of species abundance and the way they are distributed within a type of vegetation (Morlon et al., 2009). Chiacucci et al. (2010) suggest that $\alpha$ and $\beta$ relative contributions to $\gamma$ diversity depend on ecological heterogeneity or homogeneity. Our findings revealed a greater $\alpha$ diversity in most homogeneous stands like the gallery forest, whereas $\beta$ diversity is more important in the savanna vegetation types which have some similarities with a significant number of common species.

The lowest diversity of the shrub savanna linked probably to the low sampling intensity. Likewise, this type was derived from the fragmentation of the tree savanna (Sambou et al., 2015) and can be attributed to the impact of human activities such as tree cutting for firewood collection, cattle browsing and breeding damages. However, while the strategy of Arlomom project was to intervene in a buffer zone around the Patako Forest, another initiative called Nebeday recently consisted of reforestation and beekeeping activities within the forest to enhance biodiversity. The study site is biologically diverse in terms of floristic composition and could be an important provider of ecosystem services since diversity often is indicative of better ecosystem functioning (Akwee et al., 2010). The biodiversity information could be used by decision makers and conservation technicians to enhance its management and reinforce rare species in degraded areas of the Patako Forest.

\section{Structure of the woody vegetation}

The highest values of structural characteristics were recorded in the gallery forest. The basal area per hectare depended on both tree diameter sizes and density and gave 
valuable information as it is an indicator of the relevance or not to intervene in a stand in terms of forest management strategies. The importance of these structural characteristics could be related to favorable moisture conditions (Savadogo et al., 2007) that resulted in a high relative dominance of some species (Khaya senegalensis, Ceiba pentandra, Elaeis guineensis and Detarium senegalense). Most of species were mono-stemmed trees in gallery forest as opposed to other vegetation types (woodland, tree savana and shrub savana) which were dominated by multiple-stemmed species (Combretum glutinosum, Combretum nigricans, Terminalia macroptera, Acacia macrostachya). The observed stem densities were probably due to resprouting strategies as responses to stand disturbance like fires, tree cutting and recurrent stimuli experienced by some species. In certain savanna types, disturbances was perceived through the species composition and their regeneration ability and resistance characteristics that represent all different strategies of plants to survive fires (Cianciaruso et al., 2012).

Many studies have been conducted in the soudano-sahelian zone of Senegal focusing on woody vegetation structure. Our results matched with other findings that used a threshold diameter of $5 \mathrm{~cm}$ or slightly less (Sambou et al., 2008; Badji et al., 2013). This suggests the dominance of small diameter classes, especially those lower than $20 \mathrm{~cm}$. The high density of small diameter classes ensures the renewal of natural forest ecosystems while low densities of large trees result on natural selection. Similar structures have been shown in the Niokolo-Koba National Park of Senegal (Larrue, 2002) and in protected areas in the southern of Niger (Abdourhamane et al., 2013; Idrissa et al., 2020). Authors found the same profile of forest stands structure in Benin using a diameter threshold of $10 \mathrm{~cm}$ (Bonou et al., 2009; Houeto et al., 2013). This reduction described a decreasing exponential function that reaveled the potential of renewal and sustainability of forest stands (Sambou et al., 2007). However, the overall analysis of vegetation structure did not provide information about the degradation dynamics of species. Size class distributions are usually considered in sustainable management of woody vegetation. Based on that, the implementation of Patako Forest management plan should aim at an optimal conservation of woody vegetation diversity and structure.

\section{Conclusion}

The woody vegetation of Patako forest was characterized by savanna species such as Combretum glutinosum, Terminalia macroptera, Acacia macrostachya and Cordyla pinnata, whereas an important part of tree diversity was concentrated within the gallery forest, which was as a refuge for rare species. The structural characteristics indicated that in general there was a good rejuvenation potential, but it is necessary to investigate the structural characteristics of each species to get an overview of the conservation status of individual species taking into account the distribution of diameter size classes and their spatial distribution. This study has demonstrated the important contribution of savanna vegetation types for the knowledge of floristic composition and structural characteristics and particularly the potential of gallery forests for biodiversity and carbon sink conservation.

\section{COMPETING INTERESTS}

The authors declare that they have no competing interests.

\section{AUTHORS' CONTRIBUTIONS}

SS designed the research, collected and analyzed the data and produced the first draft. FND, SDD, LCF, AG, BS and CM edited and contributed to the elaboration of the methodology while AML edited and proofread the manuscript.

\section{ACKNOWLEDGMENTS}

The authors thank the UNDESERT Programme (EU-FP7 243906), 'Understanding and combating desertification to mitigate its impact on ecosystem services' for financial support and the members of the Unit of Research on Natural Ecosystems and Environment (URENE). 


\section{REFERENCES}

Abdourhamane H, Morou B, Rabiou H, Mahamane A. 2013. Caractéristiques floristiques, diversité et structure de la végétation ligneuse dans le Centre-Sud du Niger: cas du complexe des forêts classées de Dan kada Dodo-Dan Gado. Int. J. Biol. Chem. Sci., 7(3): 1048-1068. DOI: 10.4314/ijbcs.v7i3.13

Akwee PE, Palapala VA, Gweyi-Onyango JP. 2010. A Comparative study of plant species composition of grasslands in Saiwa swamp national park and Kakamega Forest, Kenya. J. Biodivers., 1(2): 77-83. DOI: 10.1080/09766901.2010.11884719

Ba AT, Noba K. 2001. Flore et biodiversité végétal au Sénégal. Sécheresse, 12(3): 149-155.

Badji M, Sanogo D, Akpo L. 2013. Effet de l'âge de la mise défens et reconstitution de la végétation ligneuse des espaces des sylvo pastoraux. J. Appl. Biosci., 64: 4876-4887.

DOI: 10.4314/jab.v64i1.88477

Bonou W, Glélé Kakaï R, Assogbadjo AE, Fonton HN, Sinsin B. 2009. Characterisation of Afzelia africana Sm. habitat in Lama forest reserve of Benin. Forest Ecol Manag., 258(7): 1084-1092. DOI: 10.1016/j.foreco.2009.05.032

Caswell H. 2001. Matrix Population Models: Construction Analysis and Interpretation ( $2^{\text {nd }}$ edn). Sinauer Associates: Massachusetts.

Chazdon RL. 2008. Beyond deforestation: restoring forests and ecosystem services on degraded lands. Science, 320(5882): 1458-1460.

DOI: 10.1126/science. 1155365

Chiarucci A, Bacaro G, Arevalo JR, Delgado JD, Fernandez-Palacios JM. 2010. Additive partitioning as a tool for investigating the flora diversity in oceanic archipelagos. Perspect. Plant Ecol. Evol. Syst., 12(2): 83-91. DOI: 10.1016/j.ppees.2010.01.001

Cianciaruso MV, Silva IA, Batalha MA, Gaston KJ, Petchey OL. 2012. The influence of fire on phylogenetic and functional structure of woody savannas:
Moving from species to individuals. Perspect. Plant Ecol. Evol. Syst., 14(3): 205-216.

DOI:

10.1016/j.ppees.2011.11.004

Crist TO, Veech JA. 2006. Additive partitioning of rarefaction curves and species-area relationships: unifying $\alpha-, \beta$ and $\gamma$ - diversity with sample size and habitat area. Ecol. Lett., 9(8): 923-932. DOI: 10.1111/j.1461-0248.2006.00941.x

Dagnelie P. 1998. Statistique Théorique et Appliquée : Inférence Statistique à Une et à Deux Dimensions. De Boeck: Bruxelles.

Diop D, Mbaye MS, Kane A, Sambou B, Noba K. 2012. Chorologie, écologie et ethnobotanique de certains Ficus sp. L. (Moraceae) au Sénégal. Biotechnol Agron. Soc. Environ., 16(1): 13-24.

Diop M, Sambou B, Goudiaby A, Niang-Diop F. 2011. Plant resources and social preferences in rural environment within Senegal. Bois For. Trop., 65: 57-68. DOI: 10.19182/BFT2011.310.A20459

Gnoumou A, Salfo S, Tiombiano A. 2020. Les groupements végétaux de la réserve de la Comoé-Léraba : caractérisation et impact des sols sur leur distribution. Int. J. Biol. Chem. Sci., 14(9): 3168-3187. DOI: 10.4314/ijbcs.v14i9.16

Gotelli NJ, Colwell RK. 2001. Quantifying Biodiversity: procedures and pitfalls in the measurement and comparison of species richness. Ecol. Lett., 4(4): 379$391 . \quad$ DOI: $\quad 10.1046 /$ j.14610248.2001.00230.x

Houeto G, Fandohan B, Ouedraogo A, Ago E, Salako VK, Assogbadjo AE, Glèlè Kakaï R, Sinsin B. 2013. Floristic and dendrometric analysis of woodlands in the Sudano-Guinean zone: a case study of Belléfoungou forest reserve in Benin. Acta Bot. Gallica., 159(4): 387-394. DOI: $10.1080 / 12538078.2012 .735124$

Huang W, Luukkanen O, Johanson S, Kaarakka V, Räisänen S, Vihemäki H. 2002. Agroforestry for biodiversity conservation of nature reserves: functional group identification and analysis. Agrofor. Syst., 55(1): 65-72. 
Idrissa I, Morou B, Abdourhamane H, Karim S, Abdourhamane T, Djibo I, Mahamane A. 2020. Diversité floristique et structure démographique des peuplements ligneux des parcours naturels sahéliens du SudEst du Niger: Cas de l'enclave pastorale « Dadaria ». (Mainé-Soroa, Diffa). Int. J. Biol. Chem. Sci., 14(3): 706-721. DOI: 10.4314/ijbcs.v14i3.6

Jurasinski G, Retzer V, Beierkuhnlein C. 2009. Inventory, differentiation, and proportional diversity: a consistent terminology for quantifying species diversity. Oecologia, 159: 15-26. DOI: 10.1007/s00442-008-1190-z

Larrue S. 2002. Le Parc National du NiokoloKoba: un exemple de rupture entre le milieu et la société mandingue (Sénégal Oriental)? Les Cahiers d'Outre-Mer. 218: 149-174. DOI: $10.4000 / \mathrm{com} .1076$

Lele S, Wilshusen P, Brockington D, Seidler R, Bawa K. 2010. Beyond exclusion: alternative approaches to biodiversity conservation in the developing tropics. Curr. Opin. Environ. Sustainability, 2(12): 94-100. DOI: 10.1016/j.cosust.2010.03.006

Magurran AE. 2004. Measuring Biological Diversity. Blackwell Science: Oxford.

Morlon H, White EP, Etienne RS, Green JL, Ostling A, Alonso D, Enquist BJ, He F, Hurlbert A, Magurran AE, Maurer BA, McGill BJ, Olff H, Storch D, Zillio T. 2009. Taking species abundance distributions beyond individuals. Ecol. Lett., 12(6): 488-501. DOI: 10.1111/j.1461-0248.2009.01318.x

Ouoba PA, Da DEC. 2019. Woody plants structure and composition in Burkina Faso Sahel: case study in Kékénéné village. Int. J. Biol. Chem. Sci., 13(3): 1682-1692. DOI: 10.4314/ijbcs.v13i3.38

Porter-Bolland L, Ellis EA, Guariguata MR, Ruiz-Mallen I, Negrete-Yankelevich S, Reyes-Garcia V. 2012. Communitymanaged forests and forest protected areas: an assessment of the conservation effectiveness across the tropics. Manag. Forest. Ecol., 268: 6-17. DOI: 10.1016/j.foreco.2011.05.034
Sambou B, Bâ AT, Goudiaby A, Sonko I, Mbow C. 2007. Étude de la flore et de la végétation ligneuse pour la détermination des types d'usages compatibles avec une gestion durable de la forêt classée de Patako (Sénégal). Webbia, 62(1): 85-96.

Sambou B, Bâ AT, Mbow C, Goudiaby A. 2008. Studies of the woody vegetation of the Wélor forest reserve (Senegal) for sustainable use. W. Afr. J. Appl. Ecol., 13(1): 67-76. DOI: 10.4314/wajae.v13i1.40577

Sambou B. 2004. Evaluation de l'etat, de la dynamique et des tendances évolutives de la flore et de la végétation ligneuses dans les domaines soudanien et sub-guinéen au Sénégal. Rapport scientifique, Université Cheikh Anta Diop, Dakar.

Sambou S, Lykke AM, Sambou H, Sambou B, Guiro I, Mbow C. 2015. Land use-land cover change and drivers of deforestation in the Patako protected area (Center-West of Senegal). Am. J. Environ. Prot., 4(6): 306-317.

DOI: 10.11648/j.ajep.20150406.17

Savadogo P, Tigabu M, Sawadogo L, Odén PC. 2007. Woody species composition, structure and diversity of vegetation patches of a sudanian savanna in Burkina Faso. Bois For. Trop., 294(4): 5-20.

Sfenthourakis S, Panitsa M. 2012. From plots to islands: species diversity at different scales. Diversity patterns in insular plants communities. J. Biogeogr., 39(4): 750759.

DOI: 10.1111/j.1365.2699.2011.02639.x

Sheykholeslami A, Kia Pasha K, Kia Lashaki A. 2011. A study of tree distribution in diameter classes in natural forests of Iran (case study: Liresara forest). Ann. Biol. Res., 2(5): 283-290.

Stork NE. 2010. Reassessing current extinction rates. Biodivers Conserv., 19: 357-371. DOI: 10.1007/s10531-009-9761-9

Thompson ID, Guariguata MR, Okabe K, Bahamondez C, Nasi R, Heymell V, Sabogal C. 2013. An operational framework for defining and monitoring forest degradation. Ecol. Soc., 18(2): 20. DOI: $10.5751 /$ ES-05443-180220 